International Journal of Instruction e-ISSN: 1308-1470 • www.e-iji.net

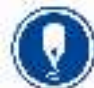

July $2021 \bullet$ Vol.14, No.3

p-ISSN: 1694-609X

pp. 873-892

Article submission code

20200726060400

Received: $26 / 07 / 2020$

Revision: 30/01/2021

Accepted: 22/02/2021

OnlineFirst: 19/06/2021

\title{
The Influence of 4C (Constructive, Critical, Creativity, Collaborative) Learning Model on Students' Learning Outcomes
}

\section{Ilyas Supena}

Islamic State University Wali Songo Semarang, Indonesia,

ilyassupena@walisongo.ac.id

Agus Darmuki

IKIP PGRI Bojonegoro, Indonesia, agus_darmuki@yahoo.co.id

\author{
Ahmad Hariyadi \\ IKIP PGRI Bojonegoro, Indonesia, ahmadhariyadi86@gmail.com
}

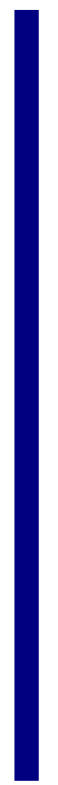

\begin{abstract}
This study aimed to investigate: 1) the influence of $4 \mathrm{C}$ learning model on students' learning outcomes in the philosophy of science course, 2) the influence of academic capability on students' learning outcomes in the philosophy of science course, and 3) the interaction between $4 \mathrm{C}$ learning model and academic capability on the students' learning outcomes in the philosophy of science course, in cognitive, psychomotor, and affective domains at UIN Walisongo Semarang academic year of 2019/2020. This study was a quasi-experimental research with $2 \times 3$ factorial design. The study was conducted at UIN Walisongo Semarang academic year of 2019/2020 on the first years students of Islamic Communication Department. Techniques in collecting the data were multiple choise tests, essay tests, observations, and documentation. The hypothesis testing used two-way ANOVA test with a significance level of 5\%. The result of it related to the influence of $4 \mathrm{C}$ model on the students' learning outcomes had showed the significance values in cognitive, psychomotor, and affective domains. The value of cognitive domain was 0.314 , the value of psychomotor domain was 0.032 , and the value of affective domain was 0.038 . The result of hypothesis testing used two-way ANOVA test related to the influence of academic capability on the students' learning outcomes had showed the the significance values in cognitive, psychomotor, and affective domains. It was suggested to implement $4 \mathrm{C}$ learning model that would influence the students' learning outcomes.
\end{abstract}

Keywords: 4C learning model, learning outcomes, academic capability, philoshopy of science, learning

\section{INTRODUCTION}

Nowadays, the issue that is interesting and widely discussed internationally is about the Fourth Industrial Revolution (or Industry 4.0) in various field including education field

Citation: Supena, I., Darmuki, A., \& Hariyadi, A. (2021). The Influence of 4C (Constructive, Critical, Creativity, Collaborative) Learning Model on Students' Learning Outcomes. International Journal of Instruction, 14(3), 873-892. https://doi.org/10.29333/iji.2021.14351a 
(Trilling \& Fadel, 2009; Arsad et.al., 2011; Osman et.al., 2013; Kivunja, 2014; Griffin \& Care, 2015; Egan et.al., 2017; ). This issue is also interesting and developing in Indonesia especially in education field (Zubaidah et. al., 2016). The science and technology developments have changed the world as the fourth industrial revolution. The Industry 4.0 as a phase of technology revolution has changed the human's way in having activities compared to their previous life experiences. Facing the industry 4.0 is not easy, so we have to prepare many things related to it. One of the important elements that must be a concern to improve the economic growth and national competitiveness in this era is to prepare a more innovative learning system and improve the graduates competences who have learning and innovation skill in the $21^{\text {st }}$ century. It causes this century is more focussed on spesific specializations, so the Indonesian national education goals must be directed to create skill and attitude of individuals in the $21^{\text {st }}$ century.

The five main domain in the $21^{\text {st }}$ century are digital literacy, intensive thinking, effective communication, high productivity, and also the spiritual and moral values (Trilling \& Fadel, 2009; Egan et.al., 2017). Brown (2015: 58-60) classifies the skill and attitude in the $21^{\text {st }}$ century are as the ways to think (knowledge, critical, and creative thinking), ways to learn (literacy and softskills), and way to learn with other (personal, social, and civic responsibilities). The US-based Partnership for $21^{\text {st }}$ century skills (P21) identifies critical thinking skills, creative thinking skills, communication skills, and collaboration skills as competensies that are needed in the $21^{\text {st }}$ century. This competence is known as $4 \mathrm{C}$ competency.

Critical thinking skill is a fundamental skill in solving problems (Lang, 2000: 21). The skill is important to be possessed by students in finding the problem sources and the right solution for it. The critical thinking skill can be instilled in various disciplines. The teacher plays an important role in designing and developing the learning programs to be focussed on empowering this skill. The creative thinking skill is related to the skill that implements a new approach to solve a problem and be an innovation. This skill is completely new and original action both personally and culturally (Facione, 2010). Some examples of students' creative thinking skill are their willingness to think about problems or challenges, share it with others, and settle for feedbacks. The communication skill is a skill to express ideas, thoughts, knowledge, or new informations in written and oral forms (NEA, 2010). This skill includes listening, writing, and speaking skills (Darmuki et.al., 2018; Darmuki et al., 2017; Darmuki et.al, 2019). The collaboration skill is a skill to work together effectively and efficiently that shows respect for diverse teams, practices fluency and willingness in making decision needed to achieve common goals (Greenstein, 2012; NEA, 2012). Groupworks or teamworks consist of leadership, decision making, and cooperation (Darmuki \& Hidayati, 2019; Darmuki \& Hariyadi, 2019).

The Indonesian learning process (including philosophy of science learning) has many weaknesses. One of them is the lack of students' thinking skill. Zubaidah (2018) states that the philosophy of science learning is said to be qualified when it is challenging, enjoyable, encourages exploration, provides successful experiences, and develops 
thinking skill. This argument is supported by Sutiman et.al (2014) who argues that the learning process of philosophy of science has to prepare qualified students who have scientific literacy, good attitudes, and higher order thinking skills. It creates human resources that are able to think critically and creatively, make decisions, and solve problems.

One of thinking skills that is expected to emerge in philosophy of science learning is critical thinking skill. It is individual skill that is used to analyse arguments and provides interpretations based on rational perceptions, assumption analysis, and logical interpretation. Critical thinking can stimulate students to solve the problems that are related to the learning materials (Ewie, 2010). The critical thinking skill is curious thinking about the available information to reach a deep understanding. According to Beyer (1995), it includes interpretation, analysis, inference, evaluation, explanation, and self-regulation. The students' interpretation aspects are able to classify the problems received so it has clear meanings. The students' analysis aspects are able to test ideas and recognize the reasons and statements. The students' inference aspects are able to make a conclusion in problem solving. The students' evaluation aspects are able to assess opinions or statements received from themselves and another people. The students' explanation aspects are able to explain expressed statements to be a strong opinion. The students' self-regulation aspects are able to regulate their existences in dealing with problem solving. The development of critical thinking skill is the integration of several parts of skill development such as observation, analysis, reasoning, assessment, and decision making. The better development of these abilities will make us able to overcome the problems with satisfying results.

Ennis (2011) states that critical thinking has two components, namely: 1) the ability to produce and process informations, 2) the habit of using skills to control behavior based on intellectual commitment. The critical thinking consists of some aspects. They are self-guided, self-disciplined, self-directed, self-monitored, and self-corrective thinking to have higher thinking. When those aspects are fulfilled, it will make people who think critically have rational life, be consistent and empathic person.

The philosophy of science learning aims to make students able to understand the concepts of scientific thinking, be able to apply the concepts being learned, be able to relate one concept to another concepts, and be able to solve dailylife problems. Sutiman et.al (2014) argue that study the philosophy of science is not only gathering knowledge, but also empowering thinking skill, scientific skill, and its implementation on students. The perception of philosophy of science lecturers is limited to the product, as a result the learning has not been student-centered. The aim of its learning is changed to how much students can memorize the concept of scientific thinking. The aspect of critical thinking is rarely trained by lecturers, as a result the students' critical thinking skills are cause for concern. Knowledge can be meaningfully constructed when the lecturer is able to train students to think critically in analysing and solving a problem. Students who think critically will be able to identify, evaluate, construct arguments, and be able to solve problems correctly. 
Researchs on 4C (Constructive, Critical, Creativity, Collaborative) learning model have been widely carried out. As a research by Proulx (2004) about the integration of scientific methods and collaborative critical thinking in debate class. It shows that this method has succeeded in increasing students' debating abilities. A study by Klimoviene and Barzdziukiene (2006) which develops collaborative critical thinking to increase students' social skills in cooperative learning. Piaw (2010) has a research on the assessment of creative tests and critical thinking in classroom learning. Leen et.al. (2014) investigate the implementation of creative learning and critical thinking in Singapore schools. It shows that there is a good mastery in the learning process. A research by Zivkovil (2016) shows that critical thinking learning is very needed as an attribute to achieve success in the $21^{\text {st }}$ century. Zubaidah et.al. (2018) have a research about the importance of collaborative learning and critical thinking skill that have better results compared to Group Investigation (GI) and Jigsaw. A study by Guo (2016) about the implementation of 4C in learning Chinese shows good result and trains students' critical thinking ability. In general, the previous research has not been specific to the philosophy of science course, so the results have not focussed on the 4 learning model.

The learning designs developed in Indonesia have not demanded the students' skills and creativity in the teaching and learning process. The lecturer emphasizes more on the aspects of knowledge and understanding, while the aspects of application, analysis, synthesis, and evaluation are only done in small part of learning. The lecturers should be able to stimulate their students to think critically about the concepts of philosophy of science. Gokhale (1995) states that teaching means participating with the students in developing knowledge and meanings, being critical, holding justifications. In other words, teaching is a form of self-learning. The learning process of philosophy of science contains more lectures and exercises in answering the questions quickly without having deep understanding about the concepts. The impact of such traits causes students to be less trained to develop their reasoning ability in soving problems and applying concepts that have been learned. The main problem that causes the low ability of students to think critically is due to the learning process that has not develop the students' reasoning skills. The critical thinking skill is not the main goal of learning. In fact, the critical thinking skill plays a big role in improving the individual qualities.

The solution to solve students' critical thinking problems is the implementation of learning model that can develop their thinking skills especially critical and creative thinking skills. The learning model that is implemented is $4 \mathrm{C}$ learning model. According to Guo (2016), 4C model is an innovation in philosophy of science learning. This model has constructivist, critical, and collaborative characters that complement each other. The constructivist character in $4 \mathrm{C}$ model requires students to be able to formulate hypothesis, test hypothesis, manipulate objects, solve problems, have a dialogue, do a research, answer the questions, express ideas, raise a question, and have a reflection. This constructivist character is able to practice critical and creative thinking skills, improve the students' scientific mastery. The collaborative character enables them to cooperate each other, discuss in group, so it can equalize students' learning achievements and reduce the gap between them. 


\section{C Learning Model}

The 4C learning model has a characteristics in which knowledge is constructed by students who are active collaborative groups. Constructivist and collaborative (socioculturalism) perspectives emphasize the importance of students' participations in learning activities. The integration of constructivist-collaborative views considers that knowledge is constructed from the proccess of active individual formation and the inculturation process through social interaction. In this way, the $4 \mathrm{C}$ learning model is formed. The constructivist-collaborative learning has the concepts of schemata, assimilation, accomodation, cognitive imbalance, Zone of Proximal Development (ZPD), and scaffolding.

The $4 \mathrm{C}$ learning model requires students to learn through discussions and dialogues, so it can potentially empower the critical and creative thinkings, and improve the students' scientific mastery. The discussion and dialogue activities in $4 \mathrm{C}$ model can reduce the gap between the students who have high achievements and those who have low achievement. The $4 \mathrm{C}$ model requires the lecturers to view the class as a learning community. The students in the class are not only active in learning facts, but are also active in practicing inquiry skill such as presenting explanations, description, and predictions; controlling natural objects and events. The ideal learning community encourages students to learn from various sources including textbooks, lecturers, and the communication results between them and their lecturers.

\section{Theoretical Review}

The $4 \mathrm{C}$ learning model is a $21^{\text {st }}$ century skill that refers to the curriculum needed in the future. This learning enhances critical, constructive, collaborative, creative, and systematic thinking skills. The critical thinking was a disciplined intellectual process that actively and intelligently conceptualized, implemented, analysed, synthesized, and evaluated the informations that were generated from observation, experience, reflection, reasoning, or communication as a guidance about what was believed and the actions taken (Beyer, 1995). Another definition of critical thinking skill as stated by Bers (2005) was a mental process to analyse or evaluate information obtained from observations, experiences, common senses, or communication. In line with Facione (2010) who revealed that critical thinking was an individual skill in using his thoughts to analyse arguments and provide interpretations based on rational perceptions, assumption analysis, and logical interpretation.

Critical thinking is a process that aims to make sensible decisions about what we believe and what we do. It is a stage of higher order thinking skill. Jenicek (2006) categorized it into four groups which included problem solving, decision making, critical thinking, and creative thinking. According to Ewie (2010), reasoning included basic, critical, and creative thinkings. Researchs related to critical thinking were testing, linking, and evaluating all aspects of a situation or problem, gathering and organizing informations, determining the rational answers, drawing valid conclusions, having analytical and reflexive characters (Ennisi, 2011). 
According to Klimoviene (2006), the skills related to the concept of critical thinking were the ability to understand problems, select informations that were important to solve problems, understand the assumptions, formulate and select relevant hypotheses, draw valid conclusions, and determine the validity of it. Lang (2000) found analogies and kinds of relationships between the pieces of informations. It determined the relevance and validity of informations that could be used for problem formation and resolution, finding and evaluating solutions or other ways of problem solving.

Another basic concept related to critical thinking was attitude that included the ability to acknowledge problems and accept the general need for evidences that supported the problem (Leen, et.al, 2014). Critical thinking skill also includes the ability to show truth, knowledge about correct conclusion and abstraction, accurate generalization of some evidences, the ability to apply the knowledge. Thinking creatively implies that knowledge is the basic aspect and dimension of intellegence in the thinking process. The primary key to bring up critical thinking is to restructure thinking as a result of analysing and evaluating it effectively. Although, some experts' opinions are different, the similarity includes aspects of collecting, evaluating, and using informations effectively. The critical thinking skill is needed by students to make decisions in their lives.

Specifically, Piaw (2010) said that critical thinking skill was ability that included: 1) having observations, 2) curiosity, asking relevant questions and looking for sources needed, 3) testing and examining beliefs, assumptions, and opinions based on the facts, 4) recognizing and defining problems, 5) evaluating the validity of statements and arguments, 6) making wise decisions and valid solutions, and 7) understanding logical arguments.

According to Beyer (1995), in thinking critically the students were required to certain cognitive strategy that was appropriate to test the reliability of problem solving ideas and overcome the problems and its shortcomings. The critical thinking is a way of thinking that is directed, planned, followed logical path in line with the facts. There were six elements in critical thinking, namely 1) focus, 2) reason, 3) inference, 4) situation, 5) clarity, and 6) overview (Ennis, 2013). Critical thinking begins with the way in responding to an existing problem, so the focus of it can be seen from the conclusions of the presented arguments. Students are going to submit responses in form of underlying and logical reasons. The appropriate and sufficient reasons can be used to draw a conclusion. It is matched with the real situation. There must be a clarity of the terms used in the arguments so there is no mistake in drawing conclusion. It must be reviewed about what has been found, decided, cared for, studied, and concluded.

There were five indicators to assess critical thinking skill by using test (Piaw, 2010). They were assumptions, inferences, deductions, interpretations, and evaluating arguments. It was strengthen by Prayitno, et al (2012) who stated that the construct of thinking skill were: 1) formulating the problems, it could be measured based on students' abilities to formulate it, 2) giving arguments or opinions, it could be measured based on students' abilities to formulate the arguments needed and show various aspects of the simulated task, 3) making deduction, it could be measured based on students' abilities to make logical deduction and interpret data appropriately, 4) making induction, 
it could be measured based on the students' abilities to analyse data, make generalizations, and draw correct conclusion, 5) evaluating, it could be measured based on students' abilities to evaluate the facts, 6) deciding and taking action, it could be measured based on students' abilities to determine solutions and choose possible alternatives. Based on previous theoretical review, the hypothesis of this study was there was an influence of academic capability on students' learning outcomes in cognitive, psychomotor, and affective aspects.

\section{METHOD}

\section{Research Design}

This study was quasi-experimental research. The design of study used post-test only non-equivalent. This design took two groups, namely control group and experimental group. The control group was taught using conventional learning with varied lectures. The experimental group implemented $4 \mathrm{C}$ learning model. Both groups were given a post-test (Sugiyono, 2011). The primary data collected was then processed and analysed to find out whether there was an influence of 4C learning model on students' learning outcomes.

The stages of this study included the preparation stage, planning stage, implementation stage, observation stage, evaluation stage, analysis stage, and follow-up stage. The preparation stage prepared the learning tools that would be used in the implementation stage. The planning stage included constructing research proposal, making syllabus and lesson plan in which 4C model was applied, and preparing the research instruments.

The implementation stage was a phase of giving treatment to the research subjects and taking as much data as possible. It included the learning process in the control group and experimental group. It was observed by three person to investigate the implementation of 4C learning model by using observation sheets. After that, post-test was held.

The analysis stage was carried out after obtaining data. It was assisted using SPSS version 16. This stage was carried out until organizing the report.

\section{Participant}

The population of this study was all of the first year students in Islamic Communication Department at UIN Walisongo Semarang. This university was Islamic-based institution. Samples taken from the population had to be representative so the conclusion could be implemented for the population itself (Sukmadinata, 2007). The participant of this study were class IA as control grup consisted of 36 students (29 females and 7 males), class IB as experimental group consisted of 38 students ( 30 females and 8 males), and 2 lecturers (with 5-10 years of teaching experiences) who taught philosopy of science in Islamic Communication Department. The subjects of the study was chosen using cluster random sampling in which the samples were taken randomly (Sugiyono, 2011). Budiyono (2004) stated that in taking both classes (experimental group and control group) from the population, group equality test was used. 


\section{Data Collection}

Techniques in collecting the data were tests, documentations, and observations. Test method was a systematic procedure where the students were given a set of answers which could be shown in numbers. It consisted of questions or exercises that were used to measure knowledge, intelligence, ability or skill possessed by individual or groups (Budiyono, 2017). Test method was used to measure students' critical thinking skills. It was in form of essay tests.

The documentation method was used by collecting data in forms of notes and school documents related to the object of this study. The data was the test results of the first year students in Islamic Communication Department. The observations were done by observing the object of study directly to investigate the activities carried out (Budiyono, 2004). The observation sheets were used to examine the syntax implementation of $4 \mathrm{C}$ learning model in the classroom. It was observed all the teaching and learning process included the teacher's and students' activities, and the class condition when the $4 \mathrm{C}$ model was implemented.

\section{Data Analysis}

The analysis of data in this study used the descriptive statistical analysis and the inferential statistical analysis. The descriptive statistical analysis was used to describe the collected data such as the profile of students' critical thinking skill. The inferential statistical analysis was used to test the hypothesis. The hypothesis testing in this study used t-test of two independent samples at a significant level $(\alpha)=0,050$, and assissted by the SPSS version 16. Before t-test was carried out, the prerequisite tests were normality test using Kolmogorov Smirnov and the homogeneity test using Levene's test. The criteria used in making hypotesis decision was that $\mathrm{H}_{0}$ was rejected when the probability significance $(\mathrm{Sig})<.\alpha(0,05)$. On the other hand, $\mathrm{H}_{0}$ was accepted when the probability significance (Sig.) $>\alpha(0,05)$ (Budiyono, 2004).

\section{Validation of Data Accuracy}

The assessment of critical thinking skill used test method in forms of essay tests. The instruments that would be used to gain data had to be tested first. The instrument feasibility test was carried out in two steps, namely validity and reliability test. It was done to find out the quality level of the test items. Validity was an important quality of each test. It was the accuracy and accuracy of an instrument in carrying out its function (Sugiyono, 2011). Valid meant that the instrument could be used to measure. The validity test was testing the instrument whether it was in accordance with the philosophy of science material provided by the lecturer. It was divided into two kinds, namely internal and external validity.

The content validity was related to the ability of test in measuring the content. In other word, content validity stated whether the test had included the representative samples or not. It was able to be controlled by: 1) identifying the concepts of the materials being tested; 2) compiling a grid of materials being tested; 3) compiling test questions based on the grids, and making the answer key and rubric of assessment; 4) recheck the 
questions, the answer key, and assessment rubric before printing it out (Budiyono, 2004).

Construct validity was a validation form whether the instruments were in line with the indicators of material concepts or not. The concepts were abstract so indicators were needed to describe it. The indicators used to make the instruments to be in line with the concepts.

Measuring the indicators meant the construct of a concept. It could be concluded that if the instruments gave exact measurement of the indicators, it would give exact measurement of the materials (Sukmadinata, 2007). The construct validity were able to be measured by the expert analysis or by testing to a number of individuals out of the samples but it still was in the same population. In this study, the construct validity of instruments was tested by the expert analysis.

External validity was tested by comparing the criteria of the instruments with the empirical facts (Sugiyono, 2011). It was done by trying out the instrument on the sample of population. Validity could be measured by correlating the students' scores in one item (X) and the students' scores overall (Y) using the technique of Pearson Product Moment.

Before the questions were used to obtain the research data, the validity and reliability were tested. In testing validity, if $r$ count $>r$ table, the questions were valid. On the other hand, if $r$ count $<\mathrm{r}$ table, the questions were invalid (Sugiyono, 2011). The result of instrument validity was shown in table 1 .

Table 1

Instrument validity

\begin{tabular}{llll}
\hline Number of question & r count & r table & Conclusion \\
\hline 1 & 0.3140 & 0.3120 & Valid \\
\hline 2 & 0.3012 & 0.3120 & Invalid \\
\hline 3 & 0.3140 & 0.3120 & Valid \\
\hline 4 & 0.3012 & 0.3120 & Invalid \\
\hline 5 & 0.3140 & 0.3120 & Valid \\
\hline 6 & 0.3140 & 0.3120 & Valid \\
\hline 8 & 0.3012 & 0.3120 & Invalid \\
\hline 9 & 0.3140 & 0.3120 & Valid \\
\hline 10 & 0.3140 & 0.3120 & Valid \\
\hline 11 & 0.3012 & 0.3120 & Invalid \\
\hline 13 & 0.3140 & 0.3120 & Valid \\
\hline 14 & 0.3140 & 0.3120 & Valid \\
\hline 15 & 0.3012 & 0.3120 & Invalid \\
\hline
\end{tabular}

The value of $r_{X Y}$ was used in t-test calculation. T-test was used because the participants were the samples of population. It had to be generalized to represent all characters in the population (Budiyono, 2004). The next step examined the t-table in the significance 
level $(\alpha)$ of 0,05 and degree of freedom $(\mathrm{dk}=\mathrm{N}-2)$. The test decisions were as follows: when $t_{\text {count }}<t_{\text {table, }}$, the item was not valid, and when $t_{\text {count }}>t_{\text {table, }}$, the item was valid (Arikunto, 2009). The test item was reliable when it gave the same results in different time. The reliability-tests of test and questionnaire used Alpha cronbach test.

In testing reliability, the decision making was based on the value of Cronbach's Alpha. When the value of Cronbach's Alpha $>0,60$, the questionnaire was reliable or consistent. When the value of Cronbach's Alpha $<0,60$, the questionnaire was not reliable or not consistent (Sugiyono, 2011:193). The result of reliability test could be viewed in table 2 .

Table 2

Reliability testing

\begin{tabular}{llll}
\hline $\begin{array}{l}\text { Cronbach's } \\
\text { Alpha }\end{array}$ & $\begin{array}{l}\text { Value of Cronbach's Alpha } \\
\text { Based on Standardized Items }\end{array}$ & Number of Items & Conclusion \\
\hline 0.64 & 0.60 & 10 & Reliable \\
\hline
\end{tabular}

FINDINGS

\section{The Research Results}

The study aimed to investigate the influence of $4 \mathrm{C}$ learning model on students' creative thinking skills. The $4 \mathrm{C}$ model was implemented to the experimental group (Class IB) who consisted of 38 students. The control group (Class IA) that was consisted of 36 students were taught by using lectures and presentations. The determination of both groups was carried out using cluster random sampling. The results of post-test from both groups were compared to find out the influence of $4 \mathrm{C}$ model on the students' critical thinking skills.

The data about the students' critical thinking skill in the philosophy of science course was obtained from the written test results in form of essay. The material was about the use of deductive and inductive thinking in gaining knowledge. The essay consisted of 6 questions that included the aspects of thinking critically according to Facione (2013): interpretation, analysis, inference, evaluation, explanation, and self-regulation. The distribution result of critical thinking skills can be seen in table 3 .

Table 3

The distribution of critical thinking skill

\begin{tabular}{lll}
\hline Interval Value & Control Group Frequency & Experimental Group Frequency \\
\hline $45-52$ & 9 & 0 \\
\hline $53-60$ & 4 & 2 \\
\hline $61-68$ & 10 & 7 \\
\hline $69-76$ & 5 & 6 \\
\hline $77-84$ & 5 & 16 \\
\hline $85-92$ & 3 & 5 \\
\hline $93-100$ & 0 & 2 \\
\hline Total & 36 & 38 \\
\hline
\end{tabular}


Table 3 shows the frequency of each interval value in control and experimental groups. The biggest frequency of control group is in the interval of 61-68 with a total of 10 . While the biggest frequency of experimental group is in the interval of 77-84 with a total of 16. The data shows that the level of students' critical thinking skills in the experimental group is higher than in the control group. The description of the students' critical thinking ability can be seen in table 4 .

Table 4

The description of students' critical thinking skill results

\begin{tabular}{lll}
\hline Statistical Results & Control Group & Experimental Group \\
\hline Average & 64.92 & 76.84 \\
\hline Deviation Standard & 12.13 & 8.87 \\
\hline Variance & 147.164 & 78.731 \\
\hline Minimum & 45 & 58 \\
\hline Maximum & 87 & 93 \\
\hline Median & 64.60 & 78.25 \\
\hline $\mathrm{N}$ & 36 & 38 \\
\hline
\end{tabular}

Table 4 shows that the average value in experimental group is higher than in control group. The average value of control group is 64,92 . The average value of experimental group is 76,84 . The bigger deviation standard means the data is more heterogeneous. Otherwise, the lower deviation standaard means the data is more homogeneous. The deviation standard of control group is 12.13. The deviation standard of experimental group is 8,87 . The variance of control group is 147,164 and the variance of experimental group is 78,731 . This condition shows that the deviation standard and variance of control group is higher than experimental group. It means that the diversity (variability) of the control group is higher (Budiyono, 2017). The maximum and minimum values of experimental group are higher than control group. It is also found in the median value in which the the experimental group is higher than control group. Based on those statistical results, it can be said descriptively that the critical thinking test of the experimental students is better than the control students.

In table 4 , the average value of critical thinking skill in experimental group which implemented 4C model is higher than in control group which implemented lecture method and presentations. The comparison of average values for each aspect of critical thinking skills between the control group and experimental group could be seen in table 5 .

Table 5

The comparison between the average value of critical thinking skill in every aspect

\begin{tabular}{lllllll}
\hline Group & Interpretation & Analysis & Evaluation & Inference & Explanation & $\begin{array}{l}\text { Self- } \\
\text { Regulation }\end{array}$ \\
\hline Experimental & 83.026 & 83.026 & 77.368 & 75.789 & 83.158 & 58.947 \\
\hline Control & 91.250 & 49.444 & 68.889 & 63.333 & 61.667 & 54.444 \\
\hline
\end{tabular}

Table 5 shows that experimental group tends to be higher than control group in five aspects, namely analysis, evaluation, inference, explanation, and self-regulation. But, the control group is higher in one aspect, it is interpretation aspect. 
The critical thinking skill of control group in interpretation aspect is 91,250 , in which the interpretation aspet of experimental group is 83,026 . In analysis aspect, the control group's value is 49,444 and the experimental group's value is 83.026. In the evaluation aspect, the control group's value is 68,889 and the experimental group's value is 77,368 . In the inference aspect, the control group's value is 63,333 and the experimental group's value is 75,789 . In the explanation aspect, the control group's value is 61,667 and the experimental group's value is 83,158 . In the self-regulation aspect, the control group's value is 54,444 and the experimental group's value is 58,947 . The biggest average value of experimental group is in the explanation aspect and the biggest average value of control group is in the interpretation aspect. The lowest average value of experimental group is in the self-regulation aspect and the lowest average value of control group is in the analysis aspect. The order of the biggest to the lowest average value are analysis aspect $(33,582)$, explanation aspect $(21,491)$, inference aspect $(12,456)$, evaluation aspect $(8,480)$, interpretation aspect $(8,224)$ and self-regulation aspect $(4,503)$.

\section{Normality Test}

Testing assumption as a prerequisite for the analysis of two treatment differences with ttest needs to do statistical testing. T-test analysis requires normality test and homogeneity test. In normality test, the data has to be normal distributed. This test aims to determine both groups come from the populations which have normal distributions. $\mathrm{H}_{0}$ is stated that samples come from the normal-distributed population and $\mathrm{H}_{1}$ is stated that samples do not come from the normal-distributed population. The normality test of the data uses Kolmogorov-Smirnov test with $\alpha=0,050$ in the SPSS version 16 . The data gains from the test results of students' critical thinking skill in control and experimental groups. The decision of normality test is that if the significance value (sig) is lower than the value of $\alpha(\operatorname{sig}<0,050), \mathrm{H}_{0}$ is rejected. It means that the data is not normally distributed. If the value of sig is higher than the value of $\alpha(\mathrm{sig}>0,050), \mathrm{H}_{0}$ is accepted. It can be said that the data is normally distributed. The results of normality test can be seen in table 6.

Table 6

The results of normality test in critical thinking skill

\begin{tabular}{lllllll}
\hline Group & $\begin{array}{l}\text { Kolmogorov } \\
\text { Smirnov }\end{array}$ & $\mathrm{KS}_{\text {Table }}$ & $\mathrm{N}$ & $\mathrm{Sig}$ & \multicolumn{2}{l}{ Result } \\
\cline { 6 - 7 } & & & & Information & Decision \\
\hline Control & 0.107 & 0.227 & 36 & 0.809 & Sig $>0.05$ & Normal \\
\hline Experimental & 0.077 & 0.221 & 38 & 0.455 & Sig $>0.05$ & Normal \\
\hline
\end{tabular}

Table 6 shows that the value of sig. is higher than 0.05 , so $\mathrm{H}_{0}$ is accepted and it can be concluded that the data in both groups is normally distributed.

\section{Homogeneity Test}

The homogeneity test aims to determine whether the variance between control group and experimental group is homogeneous or heterogeneous. Homogeneous means that the data of both groups have the same variance. In this study, the homogeneity test uses Levene's test with $\alpha=0,05$ in SPSS version 16 . The variance of both groups is 
homogeneous when the significance value ( $\mathrm{sig}$ ) is more than 0,05 ( $\mathrm{sig}>0,05)$. It is said to be heterogeneous when the significance value ( $\mathrm{sig}$ ) is less than $0.05(\mathrm{sig}<0,05) . \mathrm{H}_{0}$ is said that each group has the same variance (homogeneous). $\mathrm{H}_{1}$ is stated that each group has different variance (heterogeneous). It can be seen in table 7 .

Table 7

The results of homogeneity test in critical thinking skill

\begin{tabular}{llllllll}
\hline Homogeneity Test & $\mathrm{N}$ & $\begin{array}{l}\mathrm{df} \\
1\end{array}$ & $\begin{array}{l}\mathrm{df} \\
2\end{array}$ & $\mathrm{~F}_{\text {count }}$ & $\mathrm{F}_{\text {Table }}$ & Sig & $\begin{array}{l}\text { The test decision of } \\
\mathrm{H}_{\mathrm{o}}\end{array}$ \\
\hline Critical Thinking Skill & 74 & 1 & 72 & 3.883 & 3.974 & 0.053 & Accepted \\
\hline
\end{tabular}

Table 7 shows that the value of $F_{\text {count }}$ is 3.883 and the value of $F_{\text {table }(0,05)(1)(72)}$ is 3,974 . This result shows that $\mathrm{F}_{\text {count }}<\mathrm{F}_{\text {table(0,05)(1)(72) }}$ and the significance value (sig) is more than 0,05 . It means that $\mathrm{H}_{0}$ is accepted, so the students' critical thinking skill in both groups are homogeneous. The requirements of hypothesis testing have been fulfilled in which the data comes from normal-distributed populatin and has homogeneous variance. It is carried out through t-test.

\section{Hypothesis Testing}

In this study, hypothesis testing was carried out using t-test in SPSS version 16. The aim of t-test with two samples is to compare both data and determine whether the variables are the same or different (Sugiyono, 2011). The result of prerequisite test indicates that the data is normal and homogeneous. The criteria of hypothesis testing is the significance level $(\alpha)$ is $0,05 . \mathrm{H}_{0}$ is rejected when the value of probability significance $(\operatorname{sig})<\alpha(0,05)$. And $\mathrm{H}_{0}$ is accepted when the value of probability significance $($ sig) $>$ $0.05 . \mathrm{H}_{0}$ is stated that there is no difference between the implementation of $4 \mathrm{C}$ learning model and lecturing method toward the students' critical thinking skills. The analysis results can be seen in table 8 .

Table 8

T-test results: The influence of $4 \mathrm{C}$ model on critical thinking skill

\begin{tabular}{llllllll}
\hline Variables & $\mathrm{N}$ & $\mathrm{df}$ & $\mathrm{T}_{\text {count }}$ & $\mathrm{t}_{\text {table }}$ & $\mathrm{Sig}$ & Information & Test decision of $\mathrm{H}_{\mathrm{o}}$ \\
\hline $\begin{array}{l}\text { Critical } \\
\text { Thinking Skill }\end{array}$ & 74 & 72 & 4.485 & 1.993 & 0,00 & Sig $>0.01$ & Rejected \\
\hline
\end{tabular}

Table 8 shows that the significance value is less than 0,05 . Based on it, it is concluded that $\mathrm{H}_{0}$ is rejected and $\mathrm{H}_{1}$ is accepted. $\mathrm{H}_{1}$ is stated that there are differences between the implementation of $4 \mathrm{C}$ model and lecturing method on the students' critical thinking skills. It indicates that $4 \mathrm{C}$ model influences the students' critical thinking skill because the significance value is less than 0,01 .

\section{DISCUSSION}

The analysis results using t-test reveals that $4 \mathrm{C}$ learning model influences the students' critical thinking skills. The value of sig is 0,00 ( sig $<0,05)$ and $t_{\text {count }}$ is 4,845 . The value of $t_{\text {table }}$ is 1,993 so $t_{\text {count }}>t_{\text {table }}$. The average value of students' critical thinking skill in experimental group is higher than those who are in control group $(76,84>64,92)$. This condition is because $4 \mathrm{C}$ learning model requires students to formulate problem and 
hypothesis, and test the tentative answers through group discussion and experiments. There is an inquiry process that creates students to be critical. In line with Kaddoura (2011) who said that there were differences in critical thinking skill in the aspects of analysis, evaluation, inference, deduction, and induction between the classes who were given problem based learning and the conventional learning. The learning process runs well and creates effective interactions between the lecturer and the students. It causes the aim of phylosophy of science learning is achieved. This study implements the aspects of critical thinking skill according to Facione (2013). It consisted of interpretation, analysis, inference, evaluation, explanation, and self-regulation aspects.

The 4C learning model is a combination of constructivism and collaborative views that complement each other. The constructivism view requires the students to construct their own knowledge, while the collaborative view emphasizes on the social practice and cooperation in groups. It is strengthen by Srikote's opinion (2013) who said that in the learning process, the students had to be active to construct the material concepts and solve the problems in it. Not all students can be actively involved in the learning process because of different academic capability. Therefore, it is necessary to form a heterogeneous group to encourage all students to be active. Darmuki et.al (2019) stated that in collaborative learning the students had to be grouped, so they could interact and discuss it with their friends, have strong willingness to teach another friends, and gain the benefits of collaborative learning.

The learning process that implemented $4 \mathrm{C}$ model in the experimental group run effectively. It could be viewed from the students' enthusiasm during the learning process. It was demonstrated when the lecturer applied the learning stages, they were encouraged to construct their own knowledge on the materials of the use of deductive and inductive thinking.

The implementation of $4 \mathrm{C}$ model was started by organizing the students. In this stage, the students were grouped into small groups consisted of 5 persons with different academic capability. It was intended to make the scaffolding process through peer tutorials was well facilitated. This process aimed to encourage the students with high academic capability to be able to help they who had low academic capability in construct the concepts of material. The second stage was the exploration of students' initial concepts of the material through video presentation. It aimed to encourage the conceptual changing based on constructivist idea that enabled the students to construct a new concept that was more scientific than the initial concept. The concepts were build through the process of assimilation and accomodation. The assimilation was individual process in adapting to new knowledge. The accomodation was individual process in changing the initial knowledge to create a cognitive balance (Bers, 2005).

In this stage, the students were asked to share their initial concepts or ideas about the learning materials. They were able to develop their critical thinking skill in the aspect of interpretation. This aspect was the students' skill in organizing the problems. In line with Piaget theory about constructivist learning (1986) who argued that the active learning process encouraged students to construct knowledge and understandings of facts through their experiences and interactions. The interpretation aspect had a 
difference in the average value of 8,244 between the control and experimental groups. the average value of control group was higher than experimental group because the control group began with the material presentation by the lecturer, so they were easily directed. While the experimental group began with the inquiry process.

The next stage aimed to build cognitive conflict in the students' mind to create cognitive imbalances. In this stage, the students presented slides and videos. The role of lecturer was to help them describe their ideas by asking questions. The cognitive conflict encouraged them to learn. The cognitive imbalance drove them to be unsatisfied with the phenomena until they found the right answer to balance their cognitive. Therefore, this stage developed the students' critical thinking skill in aspects of analysis and explanation. The analysis aspect occured when they tested their ideas and analysed the causes of problem. This aspect in both groups had a difference in average value of 33 , 582. The average value of experimental group was higher than control group because the constructivist process run well in experimental group. While the control group gained the materials from the lecturer only. The explanation aspect occured when the students shared their ideas and opinions to find the right answer of the problems. This aspect had a difference in average value of 21,491 . The average value of experimental group was higher than control group because the experimental group was given more opportunity and times to express their ideas.

The following stage was the conceptual bulding collaboratively. It was carried out in a constructivist manner through the process of assimilation and accomodation. This stage required the students to have inquiry activities by conducting experiment and having discussion with their collaborative groups. The students required to formulate the problem and hypothesis, and test the tentative answers. Gokhale (1955) said that in collaborative group, the students gained the basic of critical thinking when they shared their ideas, took decisions, and solved the problems. The critical thinking skill depended on the individual's understanding, belief, maturity level, and experience.

Thinking critically made the students to be more focus on the learning process rather than the facts. Critical thinking helped them to create and apply the new knowledge in their real lives so they were more creative. The process of problem formulation was carried out by asking the students to categorize the existing data. It was able to train their interpretation aspect of critical thinking skill. The process in formulating the hypothesis trained them to test the data and find the logical facts. It drove them to have analysis aspect in critical thinking skill. Testing the tentative answers trained them to compile the events and data, analyse it, and draw the conclusion. The activity of compiling the events and data was able to develop their critical thinking skill in the aspect of explanation and evaluation because they required to explain and assess the statements using strong opinions. The evaluation aspect between both groups had a difference in average value of 8,48 . The average value of experimental group in evaluation aspect was higher than control group because the $4 \mathrm{C}$ learning model based on the problems or phenomena that encouraged the students to assess the credible statements of a report. They were also able to assess inductive and deductive statements after conducting experiments (Facione, 2013). Ideally, the problem based learning could affect the students' skills in evaluating the solution of problems. 
When the experimental data had been obtained, the next activity was drawing conclusion or inference. The inference aspect had a difference in average value of 12,456 . The average value of experimental group in inference aspect was higher than control group because the students in the experimental group formulated problems, proposed hypothesis, recognized the evidences, answered the hypothesis, and drew conclusions using inductive or deductive considerations. This was in accordance with the statements of Bers (2005) and Beyer (1995), stated that students could develop the aspects of critical thinking through recognizing and obtaining its elements to draw reasonable conclusion, solve the hypothesis, consider relevant information, and reduce the consequences of data, statements, principles, evidences, opinions, concepts, and another forms of it.

The results of discussion and experiment in the collaborative groups were presented in front of the class. The presentation aimed to make the lecturer able to supervise the students' concepts, improve and strengthen it. So, they would get constructivist knowledge. They were able to differentiate the materials had been understood and not yet understood. In this way, the aspect of self-regulation in critical thinking was trained and the lecturer was the facilitator. The self-regulation aspect had a difference in average value of 4,503. The average value of control group in this aspect was lower than experimental group.

The next stage was individual quiz in the end of learning process. The quiz was in form of essay test. This stage showed the extent to which the students could understand the material they had learned. The last stage was giving rewards to the collaborative groups who were active and had increasing progress. The rewards was given to make the students understood that the learning success would be achieved if they studied harder and gave better performances than before.

The implementation of 4C learning model trained the components of students' thinking skills especially the critical thinking skill. Guo (2016) stated that 4C model consisted of schemata, assimilation, accomodation, cognitive imbalance, and scaffolding that required students to learn the construction of a concept or knowledge through discussion in collaborative groups. This learning model could trained the students' critical thinking skill.

The results of this study revealed that the implementation of $4 \mathrm{C}$ learning model in philosophy of science learning could improve the students' critical thinking skills. The researchs by Klimoviene et.al (2006) and Zivkovil (2016) concluded that there is an improvement of the students critical thinking skill through the collaborative constructivist learning. The other research that supported this study was conducted by Gokhale (1995) which stated that the collaborative-critical thinking increased the learning outcomes including the students' thinking skill.

\section{CONCLUSION}

The conclusion of this study were: 1) the 4C learning model influenced the students' psychomotor and affective learning outcomes, 2) the students' academic capability did not influence on the students' learning outcomes, and 3) the interaction between $4 \mathrm{C}$ learning model and academic capability did not influence on the first-year students' 
learning outcomes in the Islamic Communication Department of UIN Walisongo Semarang in academic year of 2019/2020. The focus of further research was needed to test the practicality and the effectiveness of $4 \mathrm{C}$ model to investigate the influence of academic capability on students' learning outcomes and their thinking abilities.

\section{REFERENCES}

Abdullah, M., \& Osman, K. (2010). Scientific inventive thinking skills among primary students in Brunei. Procedia-Social and Behavioral Sciences, 7, 294-301.

Arsad, N. M., Osman, K., \& Soh, T. M. T. (2011). Instrument development for 21st century skills in Biology. Procedia-Social and Behavioral Sciences, 15, 1470-1474.

Bers, T. (2005). Assessing Critical Thinking in Community Colleges. New Direction for Community Colleges, No. 130.

Beyer, BK. (1995). Critical Thinking. Bloomington: Phi Delta Kappa Educational Foundation.

Brown, B. (2015). Twenty First Century Skills: A Bermuda College. Twenty First Century Skil, 58-64.

Budiyono. (2004). Metodologi Penelitian Pendidikan. Surakarta: UNS Press

Budiyono. (2017). Pengantar Metodologi Penelitian Pendidikan. Surakarta: UNS Press

Darmuki, A. \& Ahmad Hariyadi. (2019). Eksperimentasi Model Pembelajaran Jucama Ditinjau Dari Gaya Belajar Terhadap Prestasi Belajar Mahasiswa Mata Kuliah Berbicara Di Prodi PBSI IKIP PGRI Bojonegoro. Kredo, 3(1), 62-72.

Darmuki, A. \& Hidayati N.A. (2019). An Investigation of The Cooperative Learning Using Audio Visual Media in Speaking Skill Subject. ICSTI, 121-126.

Darmuki, A. \& Hidayati, N.A. (2019). Peningkatan Kemampuan Berbicara Menggunakan Metode Kooperatif Tipe NHT pada Mahasiswa Tingkat I-A Prodi PBSI IKIP PGRI Bojonegoro Tahun Akademik 2018/2019. Jurnal Pendidikan Edutama, 6(2), 9-18.

Darmuki, A., \& Hariyadi, A. (2019). Peningkatan Keterampilan Berbicara Menggunakan Metode Kooperatif Tipe Jigsaw pada Mahasiswa PBSI Tingkat IB IKIP PGRI Bojonegoro Tahun Akademik 2018/2019. Kredo, 2(2), 256-267.

Darmuki, A., Andayani, J. N., \& Saddhono, K. (2017). Cooperative, Synectics, and CTL Learning Models Toward Speaking Ability Viewd from Students Motivation. Proceeding International Conference on Intellectuals 'Global Responsibility (ASSEHR), $125,75-79$.

Darmuki, A., Andayani, J. N., \& Saddhono, K. (2017). Evaluating InformationProcessing-Based Learning Cooperative Model on Speaking Skill Course. Journal of Language Teaching and Reasearch, 8(1), 44-51.

Darmuki, A., Andayani, J. N., \& Saddhono, K. (2018). The Development and Evaluation of Speaking Learning Model by Cooperative Approach. International Journal of Instruction. 11(2), 115-128. 
Darmuki, A., Hariyadi, A. \& Hidayati, N. A. (2019). Developing Beach Ball Group Investigations Cooperative. International Conferences Seword Fresh, 1-7.

Egan, A., Maguire, R., Christophers, L., \& Rooney, B. (2017). Developing creativity in higher education for 21 st century learners: A protocol for a scoping review. International Journal of Educational Research, 82, 21-27.

Ennis, R. H. (1996). Critical thinking. Upper Saddle River, NJ: Prentice-Hall Ennis, R. H. (2001). Critical Thinking Assessment.The Ohio State University. 32, (3). (Online) (http://www3.qcc.cuny.edu/WikiFiles/file/Ennis\%20Critical\%20Thinking\%20Assessme nt.pdf), diakses tanggal 6 Oktober 2018.

Ennis, R. H. (2011). The Nature of Critical Thinking: An Outline of Critical Thinking Dispositions and Abilities.(online)(http://faculty.education.illinois.edu/rhennis/ documents/TheNatureofCriticalThinking_51711_000.pdf), diakses tanggal 06 Oktober 2018

Ennis, R.H. (2013). The Nature of critical thinking: Outlines of general critical thinking dispositions and abilities. (Online). Tersedia di http://www.criticalthinking. net/longdefinition.html.

Ewie, C.U. (2010). Developing Critical Thinking Skills of Preservice Teacher in Ghana. Academic Leadership The Online Journal, 8(4), 2-10.

Facione, PA. (2010). Critical Thinking: What It Is ang Why It Counts. Insight Assesment, 1-24

Finken dan Ennis. (1993). Illinois Critical Thinking Essay Test. Illinois Critical Thinking Project. Departement of Educational Policy Studies University of Illinois. (online) (http://www.criticalthinking.net/lllCTEssayTestFinken-Ennis121993LowR.pdf), diakses tanggal 07 Oktober 2018.

Greenstein, L. (2012). Assessing 21st Century Skills: A Guide to Evaluating Mastery and Authentic Learning. California: Corwin.

Gokhale, A.A. (1995). "Collaborative Learning Enhances Critical Thinking”, Journal of Technology Education, 7(1), 22-30.

Griffin, P., \& Care, E. (2015). Assessment And Teaching of 21st Century Skills: Methods and Approach. Dodrecht:Springer Business Media.

Guo, Z. (2016). The Cultivation of 4C's in China Critical Thinking, Communication,. International Conference on Education, Management and Applied Social Science, 1-4.

Hariyadi, A. \& Darmuki, A. (2019). Prestasi dan Motivasi Belajar dengan Konsep Diri. Prosiding Seminar Nasional Penguatan Muatan Lokal Bahasa Daerah sebagai Pondasi Pendidikan Karakter Generasi Milenial. PGSD UMK 2019, 280-286.

Hotaman, D. (2008). The Examination of the basic skill levels of the students in accordance with the perceptions of teachers, parents and students. International Journal of Instruction, 1(2), 39-55.

Jenicek, M. (2006). A Physician's Self-Paced Guide to Critical Thinking. Chicago: AMA Press. 
Johnson, D.W. (2002). Meaningful Assessment A Manageable and Cooperative Process. USA: Allyn and Bacon.

Johnson, E. B. (2002). Contextual teaching and learning :what it is and why it is here to stay. London:Routledge Falmer.

Kivunja, C. (2014). Innovative pedagogies in higher education to become effective teachers of 21st century skills: unpacking the learning and innovations skills domain of the new learning paradigm. International Journal of Higher Education, 3(4), 37.

Klimoviene, G.U.J. and R. Barzdziukiene, (2006). Developing Critical Thinking Through Cooperative Learning. Study about Language, 9, 77-84.

Lang, D. (2000). Critical Thinking in Web Courses: An oxymoron? Syllabus, 14(2), 2024

Leen, C.C., Hong, H., Kwan, F.F.H. \& Ying, T.W. (2014). Creative and Critical Thinking in Singapore Schools. Singapore: National Institute of Education, Nanyang Technological University.

National Education Association. (2010). Preparing 21st century students for a global society: An educators guide to the "Four Cs". Retrieved September 16, 2018, from National Education Association: http://www.nea.org/assets/docs/A-Guide-to-FourCs.pdf

Osman, K., Hiong, L. C., \& Vebrianto, R. (2013). 21st century biology: an nterdisciplinary approach of biology, technology, engineering and mathematics education. Procedia-Social and Behavioral Sciences, 102, 188-194.

Pacific Policy Research Center. (2010). 21st Century Skills for Students and Teachers. Honolulu: Kamehameha Schools, Research \& Evaluation Division.

Partnership for 21st Century Learning. (2015). P21 Framework Definition. Retrieved September 15, 2018, from http://www.p21.org/our-work/p21framework/P21_Framework_Definitions_New_Logo2015.pdf

Piaget, J. (1986). Piaget's Theory: In Piaget and His School. Springer Berlin: Heidelberg.

Piaw, C.Y. (2010). Building a test to assess creative and critical thinking simultaneously. Procedia Social and Behavioral Sciences, 2, 551-559

Proulx, G. (2004). Integrating Scientific Method \& Critical Thinking in Classroom Debates on Environmental Issues. The American Biology Teacher, 66(1), 1-10.

Reiner, CM, Bothell, TW, Sudweeks, RR, dan Wood, B. (2002). Preparing Effective Essay Questions: A Self-directed Workbook for Educators. (Online) (https://testing.byu.edu/ handbooks/WritingEffectiveEssayQuestions.pdf, Diakses tanggal 06 Oktober 2018). 
Soland Jim, L. S. (2013). Measuring 21st Century Competencies. Singapore: Rand Coorporation.

Srikote, S. (2013). Learning English through Collaboration: A Case Study at Mahachulalongornrajavidyalaya University, Loei Buddhist College. Procedia-Social and Behavioral Sciences, 88, 274-281.

Sugiyono. (2011). Metode Penelitian Kuantitatif, Kualitatif, dan R\&D. Bandung: Alfabeta.

Sukmadinata, Nana Syaodih. (2007). Metode Penelitian Pendidikan. Bandung: Remaja Rosda Karya

Sutiman, Antuni Wiyarsi, Erfan Priyambodo. (2014). Efektivitas Pembelajaran Kooperatif dalam Meningkatkan Aktivitas dan Motivasi Belajar Mahasiswa pada Perkuliahan Filsafat Ilmu. Jurnal Pendidikan Matematika dan Sains, 2(1), 51-64.

Treffinger, D.J., Young, G.C., Selby, E.C., \& Shepardon, C. (2002). Assessing Creativity: A Guide for Educators. Florida: The National Research Center on the Gifted and Talented University of Connecticut.

Trilling, B.\& Fadel, C. (2009). 21st Century Learning Skills. San Francisco, CA: John Wiley \& Sons Wade, C. (1995). Using writing to develop and assess critical thinking. Teaching of Psychology, 22(1), 24- 28

ŽivkoviL, S. (2016). A model of critical thinking as an important attribute for success in the 21st century. Procedia-Social and Behavioral Sciences, 232, 102-108.

Zubaidah, S. (2010). Berpikir Kritis: Kemampuan Berpikir Tingkat Tinggi yang Dapat Dikembangkan melalui Pembelajaran Sains. Makalah Disampaikan pada Seminar Nasional Sains 2010 dengan Tema "Optimalisasi Sains untuk Memberdayakan Manusia” di Pascasarjana Universitas Negeri Surabaya, 16 Januari 2010.

Zubaidah, S. (2017). Pembelajaran Kontekstual Berbasis Pemecahan Masalah untuk Mengembangkan Kemampuan Berpikir Kritis. Makalah disampaikan pada Seminar Nasional dengan tema Inovasi Pembelajaran Berbasis pemecahan Masalah dalam Pembelajaran Biologi di Universitas Muhammadiyah Makasar, Makasar, 6 Mei 2017.

Zubaidah, S., Corebima, A. D., Mahanal, S., \& Mistianah (2018). Revealing the Relationship between Reading Interest and Critical Thinking Skills through Remap GI and Remap Jigsaw. International Journal of Instruction, 11(2), 41-56. https://doi.org/10.12973/iji.2018.1124a

Zubaidah, S., Corebima, A.D., \& Mistianah. (2015). Asesmen Berpikir Kritis Terintegrasi Tes Essay. Prosiding Simposium on Biology Education, Jurusan Biologi FKIP Universitas Ahmad Dahlan Yogyakarta, 4-5 April 2015.

Zubaidah, S. (2016). Keterampilan Abad ke-21: Keterampilan yang Diajarkan Melalui Pembelajaran. Seminar Nasional Pendidikan. STKIP Persada Khatulistiwa Sintang, Kalimantan Barat: STKIP Persada Katulistiwa Sintang. 